\title{
Rises in antibody to enteric Gram negative bacilli after open heart surgery: a possible mechanism for postoperative pyrexia
}

\author{
R FREEMAN, FK GOULD \\ From the Department of Microbiology, Freeman Hospital, Newcastle upon Tyne
}

ABSTRACT Paired sera, taken before operation and 10-14 days after operation from 64 patients having open heart surgery and 10 having closed heart surgery, were examined for agglutinins to seven common serotypes of Escherichia coli. The results showed that, while $20 \%$ of both groups of patients had detectable agglutinins before operation, new antibodies appeared after operation in $69 \%$ of patients having open heart surgery compared with only $10 \%$ of those having closed heart surgery, a significant difference. Thirty six pairs of sera were also examined for the preoperative presence and postoperative development of antiendotoxin. Of 22 open heart patients shown not to possess antiendotoxin before operation, 18 showed the antibody after operation, whereas none of the eight seronegative patients acquired the antibody after closed heart surgery-again a highly significant difference. These results are consistent with the hypothesis that endotoxin and other products of enteric Gram negative bacilli circulate shortly after cardiopulmonary bypass, possibly arising directly from the gut and perhaps explaining the pyrexia seen commonly at this time.

It has been suggested that one of the mechanisms leading to the colonisation of patients in intensive care units with Gram negative bacilli is the continued multiplication of the intestinal bacterial flora during periods of paralytic ileus.' It is also known that patients suffering from shock and poor tissue perfusion may develop endotoxaemia, the endotoxin being liberated directly from the gut. ${ }^{2}$ Since patients who have open heart surgery almost invariably develop paralytic ileus for 24-48 hours after operation, ${ }^{3}$ may incur ischaemic damage to the bowel mucosa ${ }^{4}$ and necessarily undergo a period of diminished tissue perfusion during cardiopulmonary bypass, ${ }^{5}$ we have investigated the possibility that release of endotoxin (and other bacterial products) from the temporarily adynamic gut might be responsible for the appreciable pyrexia $^{6}$ seen so commonly in the first one to three days after the operation.

\footnotetext{
Address for reprint requests: Dr $R$ Freeman, Department of Microbiology, Freeman Hospital, High Heaton, Newcastle upon Tyne NE7 7DN.

Accepted 15 February 1985
}

\section{Methods}

PATIENTS

Paired serum samples were taken before operation and 10-14 days after open heart surgery from 64 patients. These samples were randomly selected by one of the investigators (not concerned in the present study) from the 248 consecutive cases used in a previously reported prospective study of postperfusion hepatitis.?

Samples of serum were also obtained at similar intervals from 10 consecutive patients undergoing closed heart surgery - that is, heart surgery without cardiopulmonary bypass.

\section{SEROLOGICAL TESTING}

\section{Escherichia coli agglutination test}

Escherichia coli strains of known serotypes (O1, O2, $\mathrm{O} 8, \mathrm{O} 9, \mathrm{O} 75, \mathrm{O} 18 \mathrm{ac}$, and $\mathrm{O} 18 \mathrm{ab}$ ) were each grown overnight in nutrient broth. The broth culture was then boiled and formalin was added. The resultant inactivated suspensions of $E$ coli served as antigens in the following agglutination tests.

Serum samples were diluted 1:10 in saline and then double diluted in $0.2 \mathrm{ml}$ volumes to produce a final range of serum dilutions of 1:10-1:320. A con- 
trol tube contained saline only. To each serum dilution $0.2 \mathrm{ml}$ of the appropriate $E$ coli antigen suspension was added, so that finally each serum was tested in all dilutions against each $E$ coli serotype. Tubes were incubated in a water bath at $37^{\circ} \mathrm{C}$ overnight, placed at $4^{\circ} \mathrm{C}$ for one to two hours, and then inspected for agglutination. The highest dilution showing strong agglutination was recorded as the titre of the serum.

\section{Antiendotoxin test}

Thirty six sera were screened for the presence of antiendotoxin by a previously described qualitative method. ${ }^{8}$ Briefly, $0.2 \mathrm{ml}$ of the serum under test was added to $0.1 \mathrm{ml}$ of a mixture of endotoxins (Salomonella minnesota, $S$ typhosa, $S$ enteritidis, $S$ typhimurium, and $E$ coli O55 B5). A control tube contained serum and diluent. The resultant mixtures were incubated at $37^{\circ} \mathrm{C}$ for two hours and then held overnight at $4^{\circ} \mathrm{C}$. Tubes were then examined for the presence of a precipitate, which if present, was washed three times in buffer and then shown to contain globulin by immunofluorescence. Sera yielding such precipitates were recorded as containing antiendotoxin.

\section{STATISTICAL METHOD}

Results from the two groups were compared by $\chi^{2}$ analysis with Yates's correction for small numbers.

\section{Results}

Table 1 shows that detectable levels of $E$ coli agglutinins were found in $20 \%$ of the preoperative samples $(20.3 \%$ of candidates for open heart surgery and $20 \%$ of those having closed heart surgery). After operation, however, such agglutinins were detected in $76.6 \%$ of patients who had open heart surgery but only $30 \%$ of those who had closed heart surgery. The difference in the incidence of $E$ coli antibody in the two groups after operation is significant $(\mathrm{p}<0.05)$, but table 1 also shows that if consideration is restricted to those patients in whom new antibody appeared after operation the differences are even greater. If we take those patients in whom either a pre-existing agglutinin level increased fourfold or more or in whom agglutinins were detectable for the first time after operation, $68.75 \%$ of those having open heart surgery showed evidence of antibody formation compared with only $10 \%$ of those having closed heart surgery. This difference is highly significant $(p<0.01)$.

Table 2 presents the results of screening sera for antiendotoxin. Antiendotoxin was detected in five of the 36 preoperative sera (four open heart and one closed heart surgery) and in 23 of the postoperative samples (22 open heart and one closed heart surgery). Acquisition of antiendotoxin was most common in those patients also shown to have acquired $E$ coli agglutinins after operation, but also occurred in patients not showing postoperative changes in the agglutination test. No patient was found to have lost antiendotoxin after operation, but one patient apparently showed a rise in the agglutination test without acquisition of antiendotoxin. This was the only case of the development of agglutinins to $E$ coli $\mathrm{O} 1$, all other rises being in agglutinins to several antigens or to the single serotype $\mathbf{O} 75$.

Eighteen patients after open heart surgery acquired antiendotoxin that had not been present before operation, out of the 22 patients identified as

Table 1 Results of agglutination tests against seven Escherichia coli serotypes performed on paired serum samples from 64 patients having open heart surgery and 10 having closed heart surgery

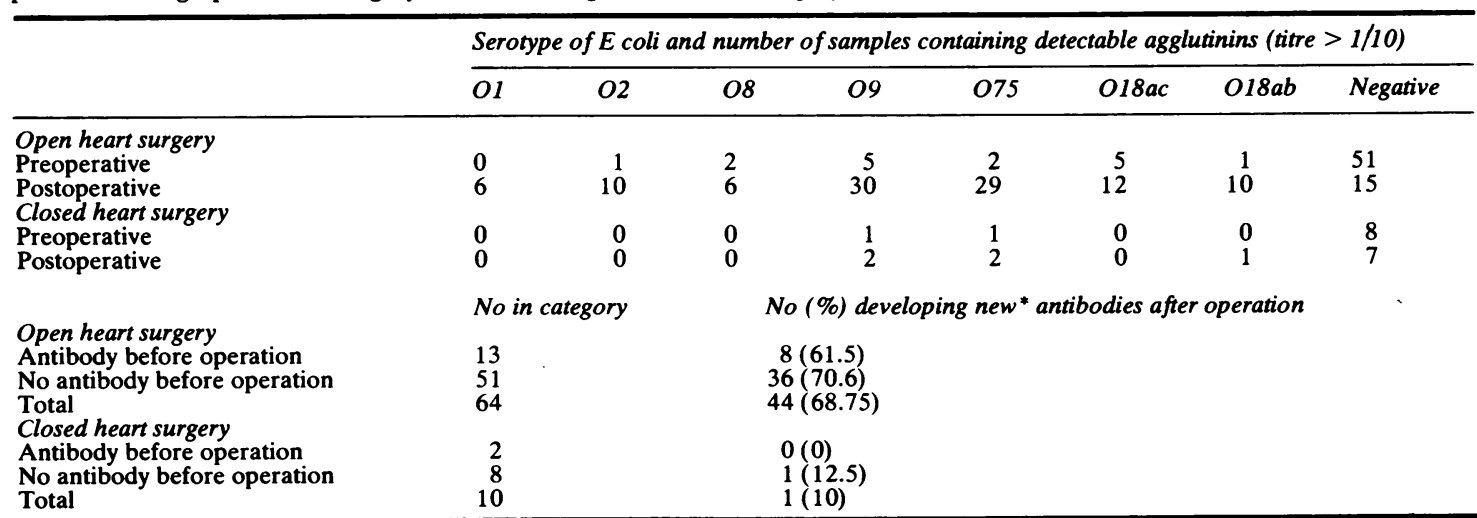

*Development of new antibody after operation implies that either antibody appeared in a patient in whom none had existed before or that a significant (fourfold or greater) increase in a pre-existing antibody level had occurred. 
Table 2 Incidence of antiendotoxin in preoperative and postoperative serum samples from 28 patients having open heart and eight having closed heart surgery and the relationship of these results to the serological results of the Escherichia coli agglutination test

\begin{tabular}{llll}
\hline Agglutination test category & No & \multicolumn{2}{c}{ No of such patients found to have antiendotoxin in } \\
\cline { 2 - 4 } & & Preoperative serum & Postoperative serum \\
\hline Open heart surgery & 6 & 1 & 6 \\
A & 3 & 0 & 2 \\
B & 9 & 1 & 8 \\
C & 10 & 2 & 6 \\
D & 28 & $4(14.3 \%)$ & $22(78.5 \%)$ \\
Total & 1 & & 0 \\
Closed heart surgery & 1 & 0 & 0 \\
A & -6 & - & 1 \\
B & 6 & 1 & $1(12.5 \%)$ \\
C & 8 & $1(12.5 \%)$ & 0 \\
Total & & & \\
\hline
\end{tabular}

${ }^{*} \mathrm{~A}-$ Preoperative agglutinins plus new antibodies after operation; B-preoperative agglutinins with no postoperative change; $\mathrm{C}-$ no preoperative agglutinins but new antibodies after operation; $D-$ no preoperative agglutinins and no postoperative change.

tSee under "Results" and "Discussion" for this sole example of an agglutinin increase without the appearance of antiendotoxin.

possessing no antiendotoxin before surgery (table 2 ); in contrast, none of the seven patients found to be antiendotoxin negative before closed heart surgery developed the antibody after operation. This difference is significant $(p<0.01)$.

There was no significant difference in the amount of blood transfused between patients in whom a rise in antibody occurred (mean 7.31, range 1-38 units) and those in whom no such rise was detected (mean 7.05 , range $2-37$ units).

\section{Discussion}

The detection of both $E$ coli agglutinins and antiendotoxin in the preoperative specimens is to be expected since both antibodies have been noted in normal individuals, including blood donors, with incidences only slightly lower than those recorded here ${ }^{84}$ The apparently higher rate of acquisition of antiendotoxin than of $E$ coli agglutinins is probably explained by the broader antigenic spectrum of the endotoxin antigen. Antibodies to Gram negative bacilli such as Klebsiella, Proteus, and so on were not sought in the agglutinin test, but other such tests are likely to have been productive. Similarly, the single discrepancy-no antiendotoxin in a patient developing postoperative $E$ coli agglutinins-may be explained by the observation that this was the only case in which agglutinin to $E$ coli $\mathrm{O} 1$ was the acquired antibody. Possibly the endotoxin mixture used, in which $E$ coli $\mathrm{O} 55 \mathrm{~B} 5$ was the sole antigen from that species, failed to react with this unusual agglutinin. These points apart, the results are remarkably consistent and show that the development of antibodies to both surface and internal antigens of enteric Gram negative bacilli is very common shortly after open heart surgery. The absence of similar findings after closed heart surgery excludes the possibility that these are cross reacting antibodies liberated from the heart during surgery, and makes it likely that their appearance is related to cardiopulmonary bypass or some other procedure distinguishing open heart from closed heart surgery. It is also possible that these antibodies may be the consequence of infection or colonisation with enteric Gram negative bacilli in early convalescence. Previous studies from this hospital, however, have documented a very low incidence of Gram negative colonisation in patients who have open heart surgery, ${ }^{10}$ and the incidence of the most common postoperative infection with such organisms (urinary tract infections) has been recently assessed in this

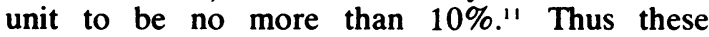
possibilities are unlikely to explain our findings.

The results presented here are consistent with the hypothesis that products of enteric Gram negative bacilli are released during or soon after open heart surgery, possibly directly from the gut, in most patients. Further studies are needed to confirm it but if this proves to be so the use of preoperative decontamination of the bowel might reasonably be expected to control the problem, with consequent benefit to the patient in the immediate postoperative period.

\section{References}

1 Atherton ST, White DJ. Stomach as source of bacteria colonising respiratory tract during artificial ventilation. Lancet 1978; ii:968-9.

2 Caridis T, Reinhold B, Woodruff PW, Fine J. 
Endotoxaemia in man. Lancet 1972;i:1381-5.

3 Walesby RK. Nutritional care in cardiac surgery. In: Longmore DB, ed. Towards safer cardiac surgery. Lancaster: MTP Press, 1980.

4 Chiu CJ, Blundell PE, Scott HJ, Gurd FN. The intestinal lesions and circulating lysosomal enzymes in extracorporeal circulation. J Thorac Cardiovasc Surg 1971;61:141-8.

5 Clowes GHA, Neville WE, Sabga G, Shibota Y. The relationship of oxygen consumption, perfusion rates and temperature to the acidosis associated with cardiopulmonary circulatory bypass. Surgery $1958 ; 44: 220-7$.

6 Freeman R. Microbiological aspects of open-heart surgery. In: Ionescu MI, Wooler GH, eds. Current techniques in extracorporeal circulation. London: Butterworths, 1976.
7 Collins JD, Bassendine MF, Codd AA. Collins A, Ferner RE, James OFW. Prospective study of posttransfusion hepatitis after cardiac surgery in a British centre. Br Med J 1983;287:1422-4.

8 Gaffin SL, Grinberg Z, Abraham C, Schechter Y. Protection against hemorrhagic shock in the cat by human plasma containing endotoxin specific antibodies. J Surg Res 1981;31:18-21.

9 Tabaqchali S, O'Donoghue DP, Bettelheim KA. Escherichia coli antibodies in patients with inflammatory bowel disease. Gut 1978;19:108-13.

10 Freeman R. Short-term adverse effects of prophylactic antibiotics for open-heart surgery. Thorax 1980;35:941-4.

11 Gould FK, Freeman R. Preoperative prediction of postoperative urinary tract infection in cardiac surgical patients. $1984 \mathrm{Br}$ Med J 1984;288:286. 